\title{
Protective Impact Of Ginkgo Biloba Extract Against Thioacetamide Induced Hepatotoxicity In Albino Rats
}

\author{
Hashim I M ${ }^{*}$, Hatim El-Hindy ${ }^{* *}$, Moussa $\mathrm{SZ}^{* * *}$ and Somaya Mansour ${ }^{* * * *}$ \\ *Veterinary Military Service \\ ***Bochemistry and Chemistry of Nutrition Department, Cairo University \\ ***Radiation Biology Department, National Centre for Radiation and Technology, Atomic \\ Energy Authority, Cairo
}

\begin{abstract}
The purpose of this study to investigate the protective and therapeutic effect of Ginkgo biloba leaves extract (GbE) against hepatotoxicity induced by thioacetamide (TAA) in male albino rats.

Rats were injected intraperitonially by TAA in a dose of $200 \mathrm{mg} / \mathrm{kg}$ b.wt. twice every week for 28 days (TAA treated group). GbE was orally administered in a dose $100 \mathrm{mg} / \mathrm{kg} \mathrm{b}$.wt. for 7 days before the first dose of TAA treatment and during exposure period (Gb protected group) and also after the last dose of TAA treatment for 28 days ( $\mathrm{Gb}$ treated group). The gained results revealed a significant increases in MDA and NO concentrations in blood and liver of TAA group with concomitant decrease in GSH, GSH-px, SOD and CAT activities. DNA fragmentation percentage, TNF- $\alpha$ concentration, hydroxyproline content and tissue transglutaminase activity were also increased. Serum transaminases, ALP and GGT activates as well as bilirubin content were increased. This study showed that Ginkgo biloba extract has a potential activity against thioacetamide. Induced hepatotoxicity and suggested that the chemical constituents of Ginkgo biloba are effective in modulation of oxidative stress induced by thioacetamide.
\end{abstract}

\section{INTRODUCTION}

Oxidative stress, characterized by the overproduction of reactive oxygen species (ROS), which overwhelm the levels of antioxidants, has been suggested as the pathogenic factor of a number of human diseases and was reported to cause tissue damage (1). ROS can damage DNA, impair protein function and increase lipid peroxidation (2). Exogenous sources of free radicals include tobacco smoke, certain pollutants and organic solvents, anesthetics, hyperoxic environments and pesticides. Some of these compounds as well as certain medications are metabolized to free radical intermediate products that have been shown to cause oxidative damage to the target tissues (3). Thioacetamide (TAA, CH3-C[S] NH2), a known fungicide used to control fruits decay
(4), was shown to be oxidized at the thioamide group to TAA sulfoxide ( $\mathrm{CH} 3-\mathrm{C}[\mathrm{SO}] \mathrm{NH} 2$ ) and subsequently di-Soxide (CH3-C[SO2] $\mathrm{NH} 2$ ) in the liver. The reactive intermediates in this pathway covalently bind to hepatic macromolecules and eventually cause liver injury $(5,6)$, whereby free radical mediated lipid peroxidation contributes to the development of TAA induced liver fibrosis $(7,8)$, Among various hepatotoxins, TAA is known to be the most potent because of its rapid elimination and cumulative injury (9). The biochemical and morphological changes observed in TAA induced rat liver injury resemble to a large extent human liver disease and could serve as a suitable model for studying the causes of human liver fibrosis and cirrhosis (10). Herbal medicine is increasingly gaining acceptance from the public and medical professionals due to advances in the 
understanding of the mechanisms by which herbs positively influence health and quality of life (11). Ginkgo biloba (maidenhair tree) is one of the oldest herbal medicines that have been used as a therapeutic agent in modern pharmacology. Ginkgo biloba has been a popular remedy in traditional Chinese medicine for over than 4000 years, and it has been a common herbal medicine in Europe since the 1730's (12). GbE is a mixture mainly of flavonoid glycosides (24\%) and terpenoides $(6 \%)$ (ginkgolides and bilobalide), has been shown to exhibit a variety of pharmacological actions (13). So, the present study was aimed to evaluate the beneficial action of Ginkgo biloba extract on hepatotoxicity induced by TAA administration in male albino rats.

\section{MATERIAL AND METHODS}

Animals and Treatment

Fivety male locally bred strain albino rats weighing $120 \pm 10 \mathrm{~g}$ were used in the current study. They were maintained on a balanced diet and water ad libitum. Animals were classified into five equal groups, 10 rats each. The $1^{\text {st }}$ group served as control, the $2^{\text {nd }}$ group was given GbE orally in a dose of $100 \mathrm{mg} / \mathrm{kg}$ b.wt. (14) daily for 28 days. The $3^{\text {rd }}$ group was injected intraperitonially by TAA in a dose of $200 \mathrm{mg} / \mathrm{kg}$ b.wt. twice weekly for 28 days (15). The $4^{\text {th }}$ group received the same dose of GbE 7 days before the first dose of TAA injection and continued during the exposure period (28 days). The $5^{\text {th }}$ group was given the same dose of GbE after the last dose of TAA treatment and continued for 28 days. At the end of experiment the animals were scarified. Blood, serum and liver samples were taken for biochemical and histopathological examination. Blood and liver samples were used for determination of MDA concentration (16), nitric oxide concentration (17), GSH concentration (18), GSH-px activity (19), SOD activity (20) and CAT activity (21). Serum samples were used for estimation of AST,ALT activities (22), ALP activity (23), GGT activity (24) and billirubin (Total, direct and indirect) (25). DNA fragmentation percentage was determined to the method of Perandones (26). TNF- $\alpha$ concentration (27), hydroxyproline content (28) and tTG activity (29), were estimated in liver samples.

Histopathology

Samples from livers were kept in $10 \%$ formalin for histopathological examination.

Statistical analysis

The SPSS (version 10) was used in data analysis. Data were analyzed with one-way analysis of variance (ANOVA) followed by a post hoc test (LSD alpha) for multiple comparisons. The data were expressed as mean \pm standard deviation $(\mathrm{SD})$. $\mathrm{P}$ values < 0.05 were considered to be statistically significant.

\section{RESULTS}

Administration of GbE to rats, by forcefeeding, for a period of 28 days, did not show significant changes in all the studied parameters, indicating that the extract did not affect lipid peroxidation and liver function test (Tables 1-5).

TAA induced significant decreases in blood and liver GSH concentration, SOD, GSH-px and CAT activities which were parallel to significant increases in MDA and NO contents (Tables 1,2). 
Table 1. Effect of GBE on erythrocytic MDA, GSH, NO levels, CAT, GSH-px and SOD activities in different experimental groups

\begin{tabular}{|c|c|c|c|c|c|}
\hline \multirow[b]{2}{*}{ Parameter } & \multicolumn{5}{|c|}{ Treatment } \\
\hline & Control & $\mathrm{Gb}$ & TAA & $\begin{array}{c}\mathrm{Gb} \\
\text { protected }\end{array}$ & $\begin{array}{c}\mathrm{Gb} \\
\text { treated }\end{array}$ \\
\hline $\mathrm{MDA} \mu \mathrm{g} / \mathrm{ml}$ & $80.07 \pm 1.94^{c}$ & $79.47 \pm 1.45^{\mathrm{c}}$ & $91.86 \pm 1.68^{\mathrm{ab}}$ & $81.44 \pm 1.22^{c}$ & $83.45 \pm 2.19^{c}$ \\
\hline $\mathrm{NO} \mu \mathrm{ml} / \mathrm{ml}$ & $17.80 \pm 0.62^{\mathrm{c}}$ & $17.86 \pm 0.32^{c}$ & $21.97 \pm 0.36^{\mathrm{ab}}$ & $17.19 \pm 0.88^{\mathrm{c}}$ & $19.72 \pm 0.35$ \\
\hline $\begin{array}{c}\text { GSH mg/dl } \\
\text { packed RBC } \\
\text { GSH-px } \mu \mathrm{g}\end{array}$ & $120.38 \pm 2.57^{\mathrm{c}}$ & $124.21 \pm 1.39^{\mathrm{c}}$ & $92.09 \pm 2.94^{\mathrm{ab}}$ & $109.37 \pm 4.86^{\mathrm{abc}}$ & $93.59 \pm 2.76^{\mathrm{ab}}$ \\
\hline $\begin{array}{l}\text { oxidized GSH/min/ml } \\
\text { packed RBCs }\end{array}$ & $231.85 \pm 21.23^{\mathrm{c}}$ & $225.31 \pm 9.92^{c}$ & $133.75 \pm 5.45^{\mathrm{ab}}$ & $207.04 \pm 12.46^{\mathrm{c}}$ & $214.11 \pm 3.44^{\mathrm{c}}$ \\
\hline $\begin{array}{c}\text { CAT } \\
\mu \mathrm{mol} / \mathrm{ml} \text { packed RBCs }\end{array}$ & $320.04 \pm 7.76^{c}$ & $135.07 \pm 5.95^{\mathrm{c}}$ & $291.85 \pm 3.00^{\mathrm{ab}}$ & $321.33 \pm 2.03^{c}$ & $322.44 \pm 1.49^{c}$ \\
\hline $\begin{array}{c}\text { SOD } \\
\mu \mathrm{g} / \mathrm{ml} \text { packed RBCs }\end{array}$ & $10.94 \pm 0.41^{\mathrm{c}}$ & $11.23 \pm 0.65^{c}$ & $8.70 \pm 0.38^{\mathrm{ab}}$ & $10.78 \pm 0.33^{c}$ & $8.75 \pm 0.44^{\mathrm{ab}}$ \\
\hline
\end{tabular}

Results are given as mean \pm S.D. for 10 rats a: significantly different from control. b: significantly different from Gb. c: significantly different from TAA.

Table 2. Effect of GBE on hepatic MDA, GSH, NO levels, CAT, GPx and SOD activities in different experimental groups

\begin{tabular}{|c|c|c|c|c|c|}
\hline \multirow[b]{2}{*}{ Parameters } & \multicolumn{5}{|c|}{ Treatment } \\
\hline & Control & $\mathrm{Gb}$ & TAA & $\begin{array}{c}\mathrm{Gb} \\
\text { protected }\end{array}$ & $\begin{array}{c}\mathrm{Gb} \\
\text { treated }\end{array}$ \\
\hline $\begin{array}{c}\text { MDA } \\
\mu \mathrm{g} / \mathrm{g} \text { tissue }\end{array}$ & $105.107 \pm 1.73^{c}$ & $104.243 \pm 1.65^{\mathrm{c}}$ & $162.990 \pm 3.09^{\mathrm{ab}}$ & $112.661 \pm 2.14^{\mathrm{c}}$ & $114.437 \pm 6.94^{c}$ \\
\hline $\begin{array}{c}\text { NO } \\
\mu \mathrm{ml} / \mathrm{g} \text { tissue } \\
\text { GSH }\end{array}$ & $70.65 \pm 1.50^{c}$ & $74.29 \pm 1.43^{\mathrm{c}}$ & $87.28 \pm 4.77^{\mathrm{ab}}$ & $81.02 \pm 7.06$ & $79.90 \pm 4.55$ \\
\hline $\mathrm{mg} / \mathrm{g}$ tissue & $158.10 \pm 3.69^{c}$ & $162.42 \pm 3.45^{\mathrm{c}}$ & $136.66 \pm 3.86^{\mathrm{ab}}$ & $150.74 \pm 2.36^{\mathrm{c}}$ & $156.71 \pm 4.43^{\mathrm{c}}$ \\
\hline $\begin{array}{c}\text { GSH-px } \\
\mu \mathrm{g} \text { oxidized GSH/ } \\
\text { min/g tissue } \\
\text { CAT }\end{array}$ & $333.45 \pm 7.48^{\mathrm{c}}$ & $345.02 \pm 6.62^{\circ}$ & $162.84 \pm 8.62^{\mathrm{ab}}$ & $348.00 \pm 7.04^{c}$ & $341.96 \pm 6.73^{\mathrm{c}}$ \\
\hline$\mu \mathrm{g} / \mathrm{g}$ tissue & $365.04 \pm 5.32^{c}$ & $373.93 \pm 6.26^{c}$ & $270.81 \pm 17.32^{\mathrm{ab}}$ & $352.74 \pm 10.61^{\mathrm{c}}$ & $357.89 \pm 3.93^{c}$ \\
\hline $\begin{array}{c}\text { SOD } \\
\mu \mathrm{g} / \mathrm{g} \text { tissue }\end{array}$ & $11.10 \pm 0.33^{\mathrm{c}}$ & $11.76 \pm 0.41^{\mathrm{c}}$ & $7.92 \pm 0.17^{\mathrm{ab}}$ & $9.71 \pm 0.35^{\mathrm{ab}}$ & $9.32 \pm 0.55^{\mathrm{abc}}$ \\
\hline
\end{tabular}

Results are given as mean \pm S.D. for 10 rats a: significantly different from control. b: significantly different from Gb. c: significantly different from TAA.

The pre-treated group with GbE showed a significant reduction of oxidative stress parameters. On the other hand, post-treatment with GbE not ameliorated neither the increases of NO content nor the depletion of GSH content and SOD activity in blood. In addition pre and post-treatment didn't ameliorated NO content in the liver.
Significant increases of serum ALT, AST, ALP and GGT activities were observed in rats that received TAA. Pre-treatment with GbE ameliorated these increases while posttreatment didn't ameliorated the increases in ALT and GGT activities Table 3. 
Table 3. Effect of GBE on ALT, AST, ALP and GGT activities in the sera of different experimental groups

\begin{tabular}{|c|c|c|c|c|c|}
\hline \multirow[b]{2}{*}{ Parameter } & \multicolumn{5}{|c|}{ Treatment } \\
\hline & Control & Gb & TAA & $\begin{array}{c}\mathrm{Gb} \\
\text { protected }\end{array}$ & $\begin{array}{c}\mathrm{Gb} \\
\text { treated }\end{array}$ \\
\hline $\begin{array}{l}\text { AST } \\
(\mathrm{U} / 1)\end{array}$ & $12.40 \pm 0.76^{\circ}$ & $11.63 \pm 0.97^{\mathrm{c}}$ & $18.30 \pm 1.46^{\mathrm{ab}}$ & $14.87 \pm 0.74^{\mathrm{c}}$ & $12.07 \pm 1.07^{\mathrm{c}}$ \\
\hline $\begin{array}{l}\text { ALT } \\
(\mathrm{U} / 1)\end{array}$ & $13.30 \pm 0.93^{\mathrm{c}}$ & $13.00 \pm 0.92^{\mathrm{c}}$ & $19.90 \pm 1.53^{\mathrm{ab}}$ & $13.43 \pm 1.07^{c}$ & $16.80 \pm 1.25^{\mathrm{b}}$ \\
\hline $\begin{array}{l}\text { ALP } \\
(\mathrm{U} / \mathrm{l})\end{array}$ & $198.33 \pm 14.50^{\mathrm{c}}$ & $187.67 \pm 18.00^{c}$ & $337.00 \pm 18.50^{\mathrm{ab}}$ & $288.67 \pm 10.41^{\mathrm{ab}}$ & $244.67 \pm 11.57^{\mathrm{ab}}$ \\
\hline $\begin{array}{l}\text { GGT } \\
(\mathrm{U} / \mathrm{l})\end{array}$ & $43.00 \pm 3.28^{\mathrm{c}}$ & $43.00 \pm 3.61^{\mathrm{c}}$ & $104.67 \pm 8.37^{\mathrm{ab}}$ & $58.33 \pm 3.93^{\mathrm{abc}}$ & $79.00 \pm 1.53^{\mathrm{ab}}$ \\
\hline
\end{tabular}

Results are given as mean \pm S.D. for 10 rats a: significantly different from control. b: significantly different from Gb. c: significantly different from TAA.

Significant increases in the content of total, direct and indirect bilirubin were observed in the rats injected with TAA. Pretreatment with $\mathrm{GbE}$ ameliorated these increases. On the other hand, post-treatment with GbE not ameliorated these increases Table 4.

Table 4. Effect of GBE on Serum billirubin total, direct and indirect concentrations in different experimental groups

\begin{tabular}{cccccc}
\hline & \multicolumn{5}{c}{ Treatment } \\
\cline { 2 - 6 } Parameter & Control & Gb & TAA & $\begin{array}{c}\text { Gb } \\
\text { protected }\end{array}$ & $\begin{array}{c}\text { Gb } \\
\text { treated }\end{array}$ \\
\hline $\begin{array}{c}\text { Bilirubin total } \\
(\mathrm{mkg} / \mathrm{ml})\end{array}$ & $0.537 \pm 0.009^{\mathrm{c}}$ & $0.513 \pm 0.041^{\mathrm{c}}$ & $0.907 \pm 0.043^{\mathrm{ab}}$ & $0.720 \pm 0.023^{\mathrm{abc}}$ & $0.800 \pm 0.047 \mathrm{ab}$ \\
$\begin{array}{c}\text { Bilirubin direct } \\
(\mathrm{mg} / \mathrm{ml})\end{array}$ & $0.237^{\mathrm{c}} \pm 0.018^{\mathrm{c}}$ & $0.253 \pm 0.020^{\mathrm{c}}$ & $0.473 \pm 0.041^{\mathrm{ab}}$ & $0.387 \pm 0.012^{\mathrm{abc}}$ & $0.407 \pm 0.024^{\mathrm{ab}}$ \\
$\begin{array}{c}\text { Bilirubin } \\
\text { indirect }(\mathrm{mg} / \mathrm{ml})\end{array}$ & $0.290 \pm 0.015^{\mathrm{c}}$ & $0.260 \pm 0.031^{\mathrm{c}}$ & $0.433 \pm 0.007^{\mathrm{ab}}$ & $0.33 \pm 0.035$ & $0.400 \pm 0.026$ \\
\hline
\end{tabular}

Results are given as mean \pm S.D. for 10 rats a: significantly different from control. b: significantly different from Gb. c: significantly different from TAA.

As shown in Table 5, TAA significantly increased liver hydroxyproline content, tTG activity, DNA fragmentation percentage and
TNF- $\alpha$ concentration. Pre and post-treatment with GbE significantly ameliorated these increases Table 5. 
on $\mathrm{CCl}_{4}$-induced liver fibrosis in Wistar male rats. They found that the liver fibrosis rats treated with GbE had decreased serum bilirubin. Finally, GbE induced striking improvement of liver function (47).

In the present study the biomarkers for liver fibrosis showed a significant increases in liver tTG activity, TNF- $\alpha$ concentrations and hydroxyproline content in TAA treated group. Several researchers have suggested that part of hepatocellular injury induced by TAA is mediated through oxidative stress caused by the action of cytokines through lipid peroxidation $(84,85)$. Free radicals activate the hepatic stellate cells (HSC) and increase the deposition of extracellular matrix (ECM) components. Also, the fibrogenesis appears to involve several events mediated by proinflammatory and cytotoxic cytokines, such as tumor necrosis factor (TNF), interleukins and transforming growth factor (TGF) $(86,87)$. Other studies, have documented the association between fibrogenesis and the excessive deposition of collagen, elastin, laminin (88) and hyaluronan (89), in the ECM. Additionally, factors involved in stabilization or degradation of these proteins may play a potential role in the progression or reversibility
of fibrosis.

Kupffer cells are the major source of mitogens, such as TNF- $\alpha$ in the liver $(90,91)$. TNF- $\alpha$ is a multifunctional cytokine (92), that acts as mediator of the acute phase response in of hepatic injury. Some authors types suggested that TNF- $\alpha$ may be necessary for hepatic proliferation (92). Elevation of TNF- $\alpha$ concentration after TAA treatment is involved in the programming of liver damage product of the inflammatory response (93).

Hydroxyproline is an amino acid unique to all of the collagens and represents $12 \%$ of amino acids in the major fibrillar collagen types I and III. Therefore, the measurement of hydroxyproline content serves as an excellent standard of fibrosis (86). In TAA treated group an increase in liver hydroxyproline content may be related to an incomplete posttranslational maturation of collagen fibrils which involves the synthesis of
hydroxyproline residues by hydroxylase; residues by prolyl 4stabilize the these residues are needed to stabilize the collagen triple helix (94).

Tissue transglutaminase (tTG) is liver derived enzyme which stabilize the scar formation. The increase in tTG activity in TAA treated group may be attributed to the increased binding of the nuclear factor-kappaB $(\mathrm{NF}-\kappa \mathrm{B})$ to the $N F-\kappa B$ motif of the $t T G$ promoter, where tTG gene expression increases during hepatic injury and fibrosis (95). The concomitant increase of both hepatic collagen and TTG activity may be explained by the dual effect exerted by the $N F-\kappa B$, which is induced by oxidative stress (96). Nevertheless, the association between tTG activity and fibrosis may involve other factors such as the factor beta (TGF- $\beta$ ), major fibrogenic growth factors, where tTG activates the latent TGF$\mu 1$, which in turn leads to de novo synthesis of tTG (97). The increase of tTG activity may also be a consequence of GSH depletion and mitochondrial dysfunction (98).

These results are consistent with previous studies which demonstrated that TAA treatment possessed hepatatoxic effect, increasing tTG activity (99,100), TNF- $\alpha$ concentration $(95,103-105)$. And decreasing
hydroxypoline content in liver (104-106).

Finally, reduced hepatic antioxidant function has also been suggested as one of the mechanism of TAA induced hepatotoxcity where, TAA decreases the level of some endogenous antioxidants including $\alpha$ -

In the present study, TAA treatment induced dramatically elevation in DNA fragmentation percentage. These increase may be a result of interaction of ROS with biological molecules, producing toxic free radicals that cause cellular DNA or protein damage and lipid-peroxidation $(108,109)$.

Results obtained in the present investigation agree with pervious study by Duthie et al. (110) who reported that TAA treatment resulted in chromosome breakage or abnormal DNA methylation. In addition 
nucleic acids can be attacked and subsequent damage to DNA can cause mutations which may be carcinogenic (3).

The present study showed that pre and post-treatment of GbE significantly reduced liver fibrosis as evidenced by significant decreases of tTG activity, TNF- $\alpha$ concentration and hydroxyproline content. These data go in hand with Harputluoglu et al., (111) who investigated that, GbE ameliorated the hepatic damage by TAA and suggested that the action of GbE may be due its free radical scavenging effects. Also Liu et al., (112) evaluated the effects of GbE on experimental liver fibrosis induced by $\mathrm{CCl} 4$ in rats and found that $\mathrm{GbE}$ was able to ameliorate liver injury through inhibiting the induction of $\mathrm{NF}-\kappa \mathrm{B}$ on HSC activation and the expression of TGF- $\beta 1$.

Pre and post-treatment with GbE significantly reversed the damage of DNA induced in TAA treated rats. Min and Ebeler (113), suggested that quercetin which is the major component of flavonoid glycosides of GbE protects against cancer by inhibiting oxidative DNA damage as well as by enhancing DNA repair after oxidant challenge in colon cells.

Histological results were in agreement with the measured parameters and provided a supportive evidence for the biochemical analysis, in the liver sections of TAA treated group, showing distorted hepatic architecture and the dense bands of fibrous tissue which is radiating from the portal vein and dissecting the liver cells. The fibrous tissue shows proliferated bile ducts, proliferated capillaries and lymphocytic infiltration. Some large and multinucleated cells were seen.

Microscopic studies revealed that, liver section of rats receiving $\mathrm{GbE}$ after TAA treatment group, showed alleviation in liver fibrosis, preserved hepatic lobular architecture and marked improvement of the portal areas was seen.

Finally, hepatoprotective activity of GbE may be due to presence of compounds in this extract with high antioxidant capacity. Studies have shown that flavonoid (ginkgo-flavone glycosides) and terpenoid (ginkgolides and bilobalides) are the most important active substances in the GbE which have antioxidant effect $(114,115)$.

In conclusion, the present study results demonstrated that $\mathrm{GbE}$ is effective in the prevention of TAA induced acute toxic effects in rats liver, which were proven by biological evaluation, biochemical analysis and further supported by the histological examinations in liver tissues. This hepatoprotective activity is both preventive (prophylactic) and curative (therapeutic).

\section{REFERENCES}

\section{Hospers $G A$, Eisenhawer $E A$ and De Vries} $E G$ (1999): The sulfhydryl containing compounds WR - 2721 and glutathione as radio - and chemoprotective agents. A review, indications for use and prospects. Br J Cancer, 80:629-638.

\section{Limon-Pacheco $j$ and Gonesbatt $M E$} (2009): The role of antioxidants and antioxidant-relaved enzymes in proflective responses to environmentally induced oxidative stress. Mutat res;674: 137-147.

\section{Lawrence J, Machlin and Adrianne} Bendich (1987): Free radical tissue damage: protective role of antioxidant nutrients. FASEB J. 1: 441-445.

4.Porter $W R$ and Neal $R A$ (1978): Metabolism of thioacetamide and thioacetamide S-oxide by rat liver microsomes. Drug Metab Dispos, 6:379388.

\section{Hunter A L, Holscher $M A$ and Neal $R A$}

(1977): Thioacetamide-induced hepatic necrosis: I. Involvement of the mixedfunction oxidase enzyme system. J Pharmacol Exp Ther, 200:439-448. 
6.Childs $J F L$ and Siegler $E$ A (1945): Uses of thioacetamide in agriculture. Science, 102:68-72.

7.Sanz $N$, Diez-Fernández C, Valverde A $M$, Lorenzo $M$, Benito $M$ and Cascales $M$ (1997): Malic enzyme and glucose-6phosphate dehydrogenase gene expression increases in rat liver cirrhogenesis. $\mathrm{Br} \mathrm{J}$ Cancer, 75:487-492.

8.Bruck R, Aeed H, Shirin H, Matas Z, Zaidel L, Avni Y and Halpern Z (1999): The hydroxyl radical scavengers dimethylsulfoxide anddimethylthiourea protect rats against thioacetamide-induced fulminant hepatic failure. J Hepatol, 31:2738.

9.Dashti H, Jeppsson B, Hagersrrand I, Hultberg B, Stinivas $U$, Abdulla $M$, Joclsson B and Bengmark $S$ (1987): Early biochemical and histological changes in rats exposed to a single injection of thioacetamide. Pharmacol Toxical, 60:171 174.

10.Muller D, Zimmerman S I and Schiller $F$ (1982): Drug metabolism in rat liver injured by thioacetamide. Arch Toxico, 5:368-371.

11.Panda $V \quad S$ and Naik $S R$ (2009): Evaluation of cardioprotective activity of Ginkgo biloba and Ocimum sanctum in rodents, Alternative Medicine Review, vol. 14, no. 2, pp. 161-171.

12.Van Beek T A, Bombardelli E, Morazzoni $P$ and Peterlongo $F$ (1998): Ginkgo biloba L., Fitoterapia, vol. 69, no. 3, pp. 195-244.

13.Van Beek TA (2005): Ginkgolides and bilobalide: their physical, chromatographic and spectroscopic properties. Bioorg. Med. Chem. ;13(17):5001-5012.

14.Liu $K X, W u W K, H e W$ and Liu C L (2007): Ginkgo biloba extract (EGb 761) attenuates lung injury induced by intestinal ischemia/reperfusion in rats: roles of oxidative stress and nitric oxide..World J.Gastroenterol., 13(2): 299305.
15.El Borai $M S$, Hessien $M$ and El-keey, $M$ $M$ (2005): Effect of alpha-tocopherol on tissue transglutaminase and reversibility of thioacetamide- induced liver fibrosis in rats. Turk J Biochem, 31(1):13-20.

16.Yoshioka T, Kawada K, Shimada $T$ and Mori $M$ (1979): Lipid peroxidation in maternal and cord blood and protective mechanism against activated oxygen toxicity in the blood. Am J Obstet Gynecol, 135:372-376.

17.Miranda $K M$, Espey $M G$ and Wink $D A$ (2001): $A$ Rapid, Simple Spectrophotometric Method for Simultaneous Detection of Nitrate and Nitrite. Online; 5(1) : 62-71.

18.Beutler E, Duron $O$ and Kelly B M (1963): Improved method of the determination of blood glutathione. J Lab Clin Med, 61(5):882-890.

19.Gross $R \quad T$, Bracci $R$, Rudolph $N$, Schroeder $E$ and Kocher $J A$ (1967): Hydrogen peroxide toxicity and detoxification in the erythrocytes of newborn infants. Blood, 29(4): 481-493.

20.Minami $M$ and Yoshikawa $H$ (1979): A simplified assay method of superoxide dismutase. Clinica Chimica Acta, 92:337342.

21.Sinha $A K$ (1972) : Colorimetric assay of catalase. Anal Biochem 47:389-394.

22.Reitman $S$ and Frankel $S$ (1957): A colorimetric method for the determination of serum glutamic oxalacetic and glutamic pyruvic transaminases. Amer J Clin Path, 28:56-63.

23.Belfield $A$ and Goldberg $D$ (1971): Normal ranges and diagnostic value of serum 5'nucleotidase and alkaline phosphatase activities in infancy. Arch Dis Child; 46(250): 842-6.

24.Rosalki $S B$ and Rau D (1972): Fundamental of clinical chemistry. Clin Chim Acta; 39: 41-47. 
25.Teitz $N W$ (1976): Fundamental of clinical chemistry. Chem Acta, 70:602-609.

26.Perandones $C$ E, Illera $V A$, Peckham $D$, Stunz $L \quad L$ and Ashman $R \quad F$ (1993): Regulation of apoptosis in vitro in mature murine spleen T cells. J Immunol, 1;151(7):3521-9.

27.Carswell $E A$, Old L J, Kassel R L, Green $S$, Fiore $N$ and Williamson $B$ (1975): An endotoxin induced serum factor that causes necrosis of tumors. Proc Natl Acad Sci USA, 72(9):3666-3670.

28.Woessner J F (1961): The determination of hydroxyproline in tissue and protein samples containing small proportions of this amino acid. Arch Biochem Biophys 93:440-447.

29. De Macedo P, Marrano $C$ and Keillor $J W$ (2000): A direct continuous spectrophotometric assay for transglutanminase activity. Annal Biochem, 285:16-20.

30.Ahsan M R, Islam KM and Bulbul I J (2009): Hepatoprotective activity of methanol extract of some medicinal plants against carbon tetrachloride-induced hepatotoxicity in rats. Eur J Sci Res; 37(2): 302-310.

31.Rahman $T M$ and Hodgson $H J$ (2000): Animal models of acute hepatic failure. Int J Exp Pathol; 81:145-57.

32.Bautista M, Andres D, Cascales M, Morales-González. J A and Sánchez-Reus M I (2010): Effect of gadolinium chloride on liver regeneration following thioacetamide-induced necrosis in rats. Int J Mol Sci; 11(11):4426-4440.

33.Sinclair A J, Barnett $A$ H and Lunie $J$ (1991): Free radical and auto-oxidant systems in health and disease. J Appl Med 1991;17:409.

34.Thirumalai T, David E, Viviyan Therasa $S$ and Elumalai E K (2011): Restorative effect of Eclipta alba in $\mathrm{CCl} 4$ induced hepatotoxicity in male albino rats. Asian Pac J Trop Dis; 1: 304-307.
35.Thabit K A, Al-Moyed M S, Al-Balushi $S$ $S$, Hasson $T A$ and Sallam (2011): Occult hepatitis B virus among chronic liver disease patients in Yemen. Asian Pac J Trop Dis; 1: 4-6.

36.Manemegalai S, Sekar $N$ and Govindaswamy $S$ (1996): Effect of vandal on tissue defense system in rats with streptozotoxic induced diabeties. J Clin Biochem Nutr., , 20, 157-164.

37.Shyamala $A$ C and Devaki $T$ (1996): Studies on peroxidation in rat ingesting copper sulphate and effect of subsequent treatment with Ocimum sanctum. J clin Biochem Nutr., 1996, 20, 113-119., 20, 113-119.

38.Samuel A J S J, Mohan S, Chellappan D $K$, Kalusalingam $A$ and Ariamuthu $S$ (2012): Hibiscus vitifolius (Linn.) root extracts shows potent protective action against anti-tubercular drug induced hepatotoxicity. J. Ethnopharmacol., 141, 396-402.

39.Hibatallah J, Carduner $C$ and Poelman $M$ $C$ (1999): In vivo and in vitro assessment of the free radical-scavenger activity of Ginkgo flavone glycosides at high concentration. J Pharm Pharmacol ;51:1435-40.

40.Dumont E, Petit E, Tarrade $T$ and Nouvelot A (1992): UV-C irradiation induced-peroxidative degradation of microsomal fatty acid and proteins: Protection by an extract of Ginkgo biloba (EGb 761). Free Radic. Biol. Med. 13, $197-$ 203.

41.Maitra I, Marcocci L, Droy-Lefaix MT and Packer L (1992): Peroxyl radical scavenging activity of Ginkgo biloba EGb 761. Free Radic. Biol. Med. 49, 1649-1655.

42.Fujii $J$ and Taniguchi $N$ (1999): The impact of TAA on glutathione peroxidase. Free Radic. Res. 31, 301-308.

43.Van Remmen H, Williams M D, Heydari $A R$ and Takahashi $R$ et al., (1996): The 
impact of TAA on glutathione peroxidase in vivo. J. Cell Physiol., 166, 453-460.

44.Anbarasu C, Rajkapoor B, Bhat KS, John Giridharan4, A Arul Amuthan and Satish $K$ (2012): Protective effect of Pisonia aculeata on thioacetamide induced hepatotoxicity in rats. Asian Pacific Journal of Tropical Biomedicine 511-515.

45.Teck Yew Low1, Chon Kar Leow, Manuel Salto-Tellez and Maxey C M Chung (2004): A proteomic analysis of thioacetamide-induced hepatotoxicity and cirrhosis in rat livers Proteomics, 4, 39603974.

46.Georgieva N, Gadjeva $V$ and Tolekova $A$ (2004): New isonicotinoylhydrazones with SSA protect against oxidative-hepatic injury of isoniazid. TJS, 2, 37-43.

47.Shi-Quan Liu, Jie-Ping Yu, Hong-Lei Chen, He-Sheng Luo, Shi-Ming Chen and Hong-Gang Yu (2006): Therapeutic Effects and Molecular Mechanisms of Ginkgo Biloba Extract on Liver Fibrosis in Rats. The American Journal of Chinese Medicine, Vol. 34, No. 1, 99-114.

48.Hayes $J D$ and McLellan L I (1999): The impact of TAA on glutathione peroxidase. Free Radic. Res., 31, 273-300.

49.Sarkar S, Yadav $P$ and Bhatnagar $D$ (1998): Lipid peroxidative damage on cadmium exposure and alterations in antioxidant system in rat erythrocytes: A study with relation to time. Biometals , 11(2):153-157.

50.Najmi A K, Pillai $K K$, Pall $S N$, Akhtar $M$, Aqil $2 M$ and Sharma $M$ (2010): Effect of l-ornithine l-aspartate against thioacetamide-induced hepatic damage in rats. 384 Indian Journal of Pharmacology | December | Vol 42 | Issue 6 | 384-387.

51.Yang J L (2001): Green Chemistry and Technology. Beijing University of Posts and Telecommunications, Beijing, China, 176-180

52.Bastianetto $S$ and Quirion $R$ (2002): Natural extracts as possible protective agents of brain aging. Neurobiol Aging, 23: 891897.

53.Dreikorn K, Berges $R$, Pientka $L$ and Jonas $U$ (2002): Phytotherapy of benign prostatic hyperplasia. Current evidencebased evaluation. Urologe A., 41(5): 447451.

54.Abdel-Rahman MK (2006): Effect of pumpkin seed (Cucurbita pepo L.) diets on benign prostatic hyperplasia (BPH): Chemical and morphometric evaluation in rats. World Journal of Chemistry, 1(1): 3340.

55.Ahlemeyer B and Krieglstein J (2003): Neuroprotective effects of Ginkgo biloba extract. Cell Mol. Life Sci., 60: 17791792.

56.Ahmad Saleem MS, Ahmad A $S$, Yousuf $S$, Ansari $M A$, Khan $M B$, Ishrat $T$, Chaturvedi $R K$, Agrawal $A K$ and Islam $F$, (2005): Ginkgo biloba affords dosedependent protection against 6hydroxydopamine-induced Parkinsonism in rats: neurobehavioural, neurochemical and immunohistochemical evidences. J Neurochemistry, 93: 94-104.

57.Robak $J$ and Gryglewski $R J$ (1988): Flavonoids are scavengers of superoxide anions. Biochem. Pharmacol. 37, 837-841.

58.Coskun O, Armutcu F, Kanter $M$ and Kuzey GM (2005): Protection of endotoxin-induced oxidative renal tissue damage of rats by vitamin $\mathrm{E}$ or/and $\mathrm{EGb}$ 761 treatment. J. Appl. Toxicol ; 25 (1):812.

59.Rimbach $G$, Gohil K, Matsugo S, Moini $H$, Saliou $C$, Virgili $F$, Weber $S U$ and Packer L (2001): Induction of glutathione synthesis in human keratinocytes by Ginkgo biloba extract (GbE 761). Biofactors, 15: 39-52.

60.Duke MV and Salim M (1985): Purification and characterization of an ironcontaining surperoxide dismutase from Eukaryote, Ginkgo biloba. Arch Biochem. Biophys., 243: 305-314. 
61.McCord J M (1985): Oxygen-derived free radicals in postischemic tissue injury. $\mathrm{N}$. Engl. J. Med., 312; 159-163.

62.Rockey DC and Chung $J J$ (1996): Regulation of inducible nitric oxide synthase in hepatic sinusoidal endothelial cells. Am J Physiol; 271: 260-267.

63.Ming-Zhe Weng, Xian-Ping Zhou, JianGuang Jia, Jing Ding, Cui-Fu Fang, YiYu Qin, Shao-Fu Tao, Long-Hua Rao, Ji-Yu Li and Zhi-Wei Quan (2011): The hepatic protective mechanism of Ginkgo biloba extract in rats with obstructive jaundice Bosn J Basic Med Sci; 11 (4): 209-213.

64.Ansil P N, Prabha S P, Nitha A, Wills $P$ $J$, Jazaira $V$ and Latha MS (2012): Curative effect of Amorphophallus campanulatus (Roxb.) Blume. tuber methanolic extract against thioacetamide induced oxidative stress in experimental rats. Asian Pacific Journal of Tropical Biomedicine S83-S89.

65.Calapai $G A$, Crupi $F$, Firenzuoli $M C$, Marciano $F$, Squadrito $G$, Inferrera $A$, Parisi A , Rizzo C, Crisafulli A, Fiore and Caputi A P (2000): Neuroprotective effects of Ginkgo biloba extract in brain ischemia are mediated by inhibition of nitric oxide synthesis. Life Sci., 67: 26732683.

66.Shen J, Wang J, Zhao B, Hou J, Gao T and Xin W (1998): Effects of EGb 761 on nitric oxide and oxygen free radicals, myocardial damage and arrythmia in ischemia-reperfusion injury in vivo. Biochem. Biophys. Acta., 1406: 228-236.

67.Sharma $H S$, Drieu $K$, Alm $P$ and Westman J (2000): Role of nitric oxide in blood-brain barrier permeability, brain edema and cell damage following hyperthermic brain injury. An experimental study using EGB-761 and Ginkgolide B pretreatment in the rat. Acta Neurochir. Suppl., 76: 81-86.

68.Du ZY and Li XY (1998): Effects of ginkgolides on interleukin-1, tumor necrosis factor-a and nitric oxide production by rat microglia stimulated with lipopolysaccharides in vitro Arzneimittelforschung /Drug Res., 48: 1126-1130.

69. Wadsworth $T L$, McDonald $T L$ and Koop $D R$ (2001): Effects of Ginkgo biloba extract (EGb 761) and quercetin on lipopolysaccharide-induced signaling pathways involved in the release of tumor necrosis factor-alpha. Biochem. Pharmacol. ; 62(7): 963-974.

70.Lippi $G$, Targher $G$, and Guidi $G C$ (2007): Ginkgo biloba, inflammation and lipoprotein(a). Atherosclerosis ; 195:417-8.

71.Kobuchi H, Droy-Lefaix M T, Christen Y and Packer L (1997): Ginkgo biloba extract (EGb 761): inhibitory effect on nitric oxide production in the macrophage cell line RAW 264. 7. Biochem Pharmacol. 53:897-903.

72.Kew MC (2000): Serum aminotransferase concentration as evidence of hepatocellular damage, The Lancet, vol. 355, no. 9204, pp. 591-592.

73.Trennery $P N$ and Waring $R H$ (1983): Early changes in thioacetamide- induced liver damage," Toxicology Letters, vol. 19, no. 3, pp. 299-307.

74.Foo $N P$, Lin $S H$, Lee $Y H, W u M J$ and Wang $Y J$ (2011): $\alpha$ - lipoic acid inhibits liver fibrosis through the attenuation of ROS-triggered signaling in hepatic stellate cells activated by PDGF and TGF- $\beta$, Toxicology, vol. 282 , no. $1-2$, pp. 39-46.

75.Neal $R A$ and Halpert $J$ (1982): Toxicity of thionosulfur compounds. Ann Rev Pharmcol Toxicol;22:321-9.

76.Kaplowitz $N$ (2001): Drug-induced liver disorders: implications for drug development and regulation," Drug Safety, vol. 24, no. 7, pp. 483-490.

77.Lee $D H$, Blomhoff $R$ and Jacobs $D R$ (2004): Is serum gamma 
glutamyltransferase a marker of oxidative stress? J Free Radic Res, 38 (6): 535-539.

78.Thabrew $M$ and Joice $P A$ (1987): A comparative study of the efficacy of Pavetta indica and Osbeckia octanda in the treatment of liver dysfunction. Planta Med., 53(3):239 - 241.

79. Achliya $G S$, Wadodkar $S G$ and Dorle $A$ $K$ (2004): Evaluation of hepatoprotective effect of Amalkadi Ghrita against carbon tetrachloride induced hepatic damage in rats. Journal of Ethnopharmacology, 90: 229- 232.

80.Moyer $V A$, Ahn $C$ and Sneed $S$ (2000): Accuracy of clinical judgment in neonatal jaundice. Arch. Pediatr. Adolesc. Med., 154, 391-394.

81.Salim Said Alkiyumi, Mahmood Ameen Abdullah, Ahmed Salim Alrashdi, Suzy Munir Salama, Siddig Ibrahim Abdelwahab and Hamid Hadi A (2012): Ipomoea aquatica Extract Shows Protective Action Against Thioacetamide - Induced Hepatotoxicity. Molecules 2012, 17, 61466155.

82.Plaa $G L$ and Hewitt W $R$ (1982): Quantitative evaluation of indices of hepatotoxicity. Toxicology of the Liver. New York: Raven Press,: 103-20.

83.Gressner $O A$, Weiskirchen $R$, and Gressner A M (2007): Biomarkers of liver fibrosis: clinical translation of molecular pathogenesis or based on liverdependent malfunction tests, Clinica Chimica Acta, vol. 381, no. 2, pp. 107113.

84.Luo $Y J, Y u J P$, Shi $Z H$ and Wang $L$ (2004): Ginkgo biloba extract reverses CCl4-induced liver fibrosis in rats, World Journal of Gastroenterology, vol. 10, no. 7, pp. 1037-1042.

85.Okuyama $H$, Shimahara $Y$, Nakamura $H$ , Araya $S$, Kawada N, Yamaoka $Y$ and Yodoi J (2004): Thioredoxin prevents thioacetamide-induced acute hepatitis. Comparative Hepatology 3: S6.
86.Friedman $S L$ (1993): The cellular basis of hepatic fibrosis: mechanisms and treatment strategies. N. Engl. J. Med. 328: 1828-1835.

87.Fey $G H$, Hocke $G M$, Wilson $D R$, Ripperger $J A$, Juan TS-C , Cui $M Z$ And Darlington $G J$ (1994): Cytokines and the acute phase response of the liver. In: The Liver: Biology and Pathobiology (3rd Ed.), edited by IM. Arias JL. Boyer N Fausto WB Jacoby, DA Schachter and DA Shafritz. New York: Raven, p. 113-143.

88.Schuppan D (1990): Structure of extracellular matrix in normal and fibrotic liver: collagens and glycoproteins. Semin Liver Dis, 10:1-10.

89.Gressner $A M$ and Haarmann $R$ (1988): Hyaluronic acid synthesis and secretion by rat liver fat storing cells (perisinusoidal lipocytes) in culture. Biochem Biophys Res Commun, 151: 222-229.

90.Decker $K$ (1990): Biologically active products of stimulated liver macrophages (Kupffer cells). Eur. J. Biochem., 192, 245-261.

91.Olynyk J K, Matuschak G M, Lechner A $J$, Britton $R S$, Tredway $T L, O^{\prime}$ Neill $R$ and Bacon $B R$ (1994): Differential production of TNF by Kupffer cells after phagocytosis of E. coli and C. albicans. Am. J. Physiol., 267, G213-G219. 13.

92.Fausto $N$ (2000): Liver Regeneration. J. Hepatol., 32, 19-31.

93. Mirandeli Bautista David Andres, María Cascales, José A. Morales-González and María Isabel Sánchez-Reus (2010): Effect of Gadolinium Chloride on Liver Regeneration Following ThioacetamideInduced Necrosis in Rats. Int. J. Mol. Sci. 2010, 11, 4426-4440

94.Prockop D J and Kivirikko K I (1995): Collagens: molecular biology, diseases, and potentials for therapy. Annu. Rev. Biochem. 64: 403-434.

95.Chen C S, Wu CH, Lai Y C, Lee W S, Chen $H M$, Chen $R J$, Chen $L C$, Ho Y 
S, Wang Y J (2008): NF-kappaB-activated tissue transglutaminase is involved in ethanol-induced hepatic injury and the possible role of propolis in preventing fibrogenesis. Toxicology, 246(2-3):148157.

96.Chen A P, Zhang L, Xu J Y, Tang J (2002): The antioxidant (-) Epigallocatechin- 3-Gallate inhibits activated hepatic a stellate cell growth and suppresses acetaladehyde induced gene expression. Biochem J, 368(3):695-704.

97.Iredale $J P$, Benyon $R C$, Pickering $J$, MaCullen M , Northrop M, Pawley S and Hovell $C$ (1998): Mechanisms of spontaneous resolution of rat liver fibrosis: hepatic stellate cell apoptosis and reduced hepatic expression of metalloproteinase inhibitors. J Clin Invest, 102:538-549.

98.Lesort $M$, Tucholski J , Zhang $J$ and Johnson $G \quad V \quad$ (2000): Impaired mitochondrial function results in increased tissue transglutaminase activity in situ. J Neurochem, 75(5):1951-196.

99.Greenberg $C S$, Birckbichler $P J$ and Rice $R H$ (1991): Transglutaminases: multifunctional cross-linking enzymes that stabilize tissues. FASEB J, 5:3071-3077

100.Whitfield J B (2001): Gamma glutamyl transferase. Crit Rev Clin Lab Sci, 38 (4): 263-355.

101.Akbay A, Cinar K, Uzunalmoglo $O$, Eranil, $S$, Yurdaydin, C , Dozkaya, H' and Bozkaya $M$ (1999): Serum cytotoxin in $\mathrm{N}$-acetyl-cysteine treated thioacetamide hepatotoxicity of rat. Human Exp. Tox, 18: $669-676$.

102.Chu C J, Chen $C T$ and Wang $S S$, et al (2001): Hepatic encephalopathy in rats with thio12. acetamide induced fulminant hepatic failure: role of endotoxin and tumor necrosis factor- $\alpha$. Chin Med J;64:321-330.

103.Ulvi Demirel1, Murat Mmharputluoglu, Yuksel Seckin, Harun Ciralik, Ismail Temel, Fatma Ozyalin, Baris Otlu, Bilgic Yilmaz, Mehmet Sarp Dincturk and Hulya
Aladag (2010): An antibody of TNF-alpha did not prevent thioacetamide-induced hepatotoxicity in rats. Human and Experimental Toxicology 000(00) 1-7.

104.Johnson T S, El-Koraie A F, Skill NJ, Baddour N M, El Nahas A M, Njloma $M$ , Adam A $G$ and Griffin $M$ (2003): Tissue transglutaminase and the progression of human renal scarring. J Am Soc Nephrol, 14(8):2052-2062.

105.Tsukada S, Parsons $C J$ and Rippe $R A$ (2006): Thioacetamide-Induced Liver Fibrosis in Mice: The Role of Kupffer Cells. Clin. Chim. Acta, 364, 33-60.

106.Mansour $S Z$ and El-Kabany $H$ (2009): Effects of Fructus Piperis Longi extract on fibrotic liver of gamma-irradiated rats. Chinese Medicine, 4:2 doi:10.1186/17498546-4-2.

107.Balkan $J$, Dogru-Abbasoglu $S$, Kanbagli $O$, Cevikbas $U$, aykac-Toker $G$ and Uysal M (2001): Taurine has a protective effect against thioacetamideinduced liver cirrhosis by decreasing oxidative stress. Hum Exp Toxical, 20(5):251-254.

108.Sener $G$, Jahoric $N$ and Tosun $O$ (2003): Melatonin omeliorates ionizing radiation-induced oxidative organ damage in rats. Life sci 74:563-572.

109.Srinivasan $M$, Sudheer $A R$ and Pillai $K$ $R$, et al (2007): Lycopene as a natural protector against $\gamma$-irradiation induced DNA damage, lipid peroxidation and antioxidant status in primary culture of isolated rat hepatocytes in vitro. Biochim Biophys Acta 2007; 1770: 659 - 665.

110.Duthie $S \mathrm{~J}$ and $\mathrm{Br}$ Med Bull (1999): DNA fragmentation. 55, 578-592.

111.Harputluoglu M M M, Demirel $U$ and Ciralik $H$ et al, (2006): Protective effects of Gingko biloba on thioacetamide-induced fulminant hepatic failure in rats, Human and Experimental Toxicology, vol. 25, no. 12, pp. 705-713. 
112.Liu $S Q, Y u J P$, Chen $H L$, Luo $H S$, Chen $S M$ and $Y u$ H $G$ (2006): Therapeutic effects and molecular mechanisms of Ginkgo biloba extract on liver fibrosis in rats. Am J Chin Med. 34: 99114.

113.Min $K$ and Ebeler $S E$ (2009): Quercetin inhibits hydrogen peroxide-induced DNA damage and enhances DNA repair in Caco2 cells. Food Chem Toxicol, 47(11):27162722.
114.Itil T and Martorano D (1995): Natural substances in psychiatry (Ginkgo biloba in dementia). Psychopharmacol. Bull., 31: $147-158$.

115.Cha'vez-Morales $R \quad M$, JaramilloJuárez F, Posadas del Ri'o FA, ReyesRomero M A , Rodri'guez-Va'zquez, M L and Marti'nez-Saldaña MC (2010): Protective effect of Ginkgo biloba extract on liver damage by a single dose of $\mathrm{CCl} 4$ in male rats. Human and Experimental Toxicology, 30 (3): 209-216.

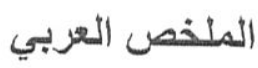

التأثير الوقاني لمستخلص نبات الجنكوبيلوبا علي التسمم الكبدي المحدث بماده الثايواسيتاميد في الجرزان البيضاء الثهياء

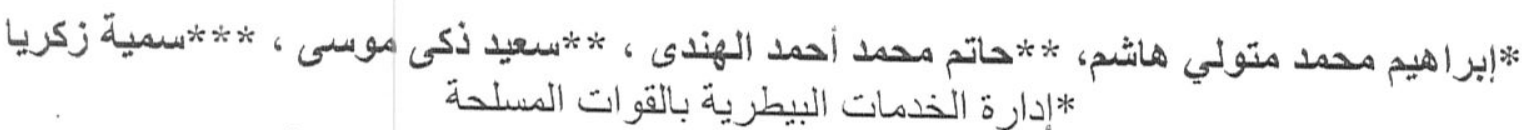

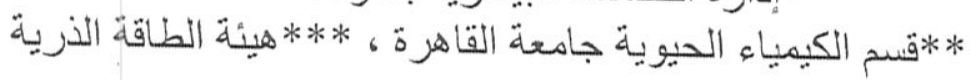

الغرض من هذه الدر اسة هو التعرف على تأثير الوقائي و العلاجي من مستخلص أورق الجنكوبيلوبا.

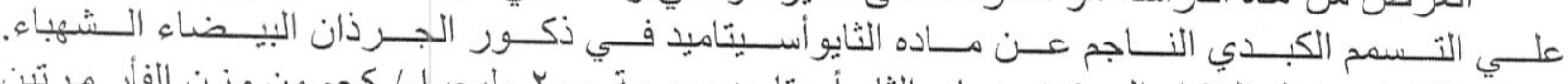

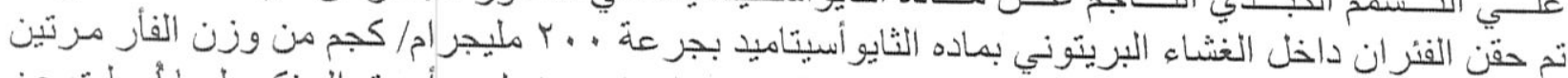

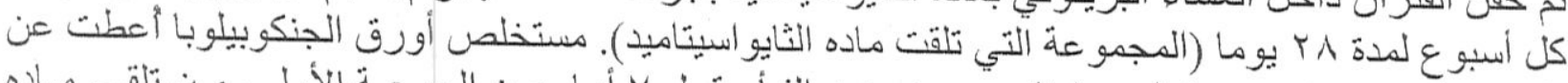

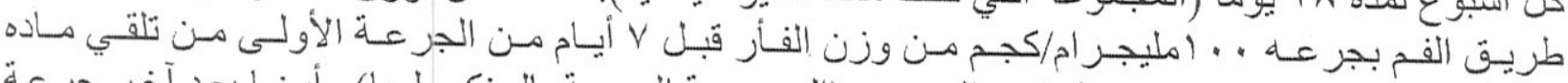

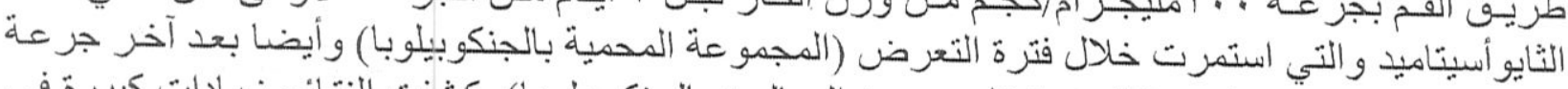

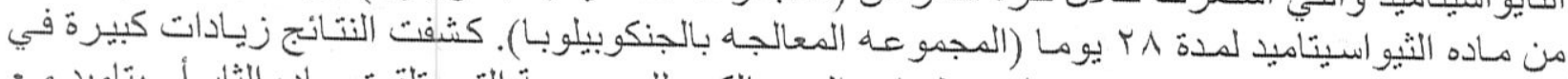

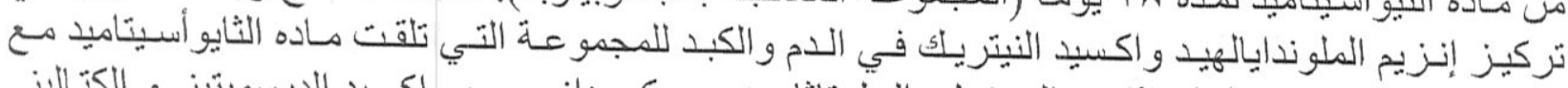

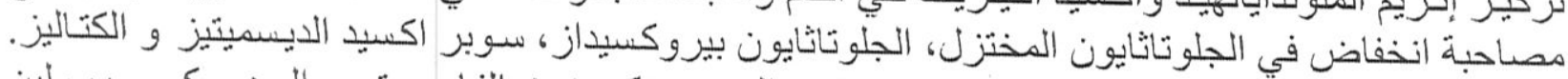

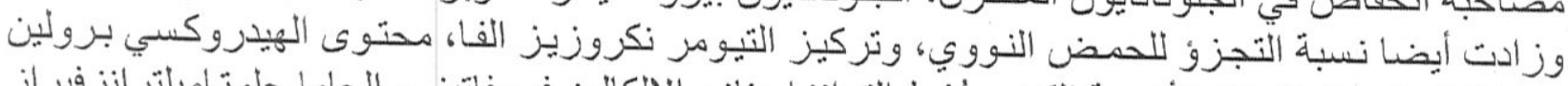

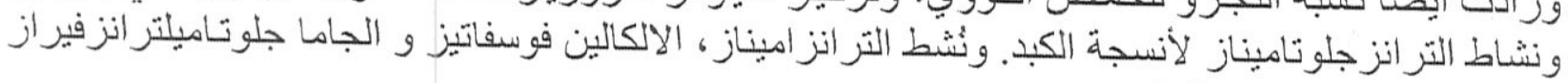
فضلا عن زياده محتوى البيلبروبين.

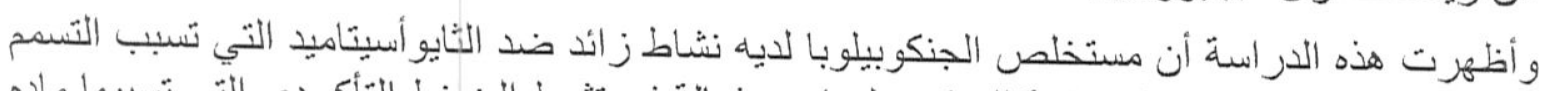

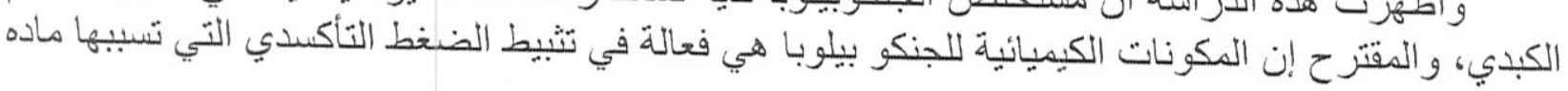

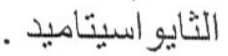

